\title{
Lexicon pentaglotton - suomea sisältävä viisikielinen sanakirja 1600-luvulta
}

\section{Johdanto}

Varhaisin tunnettu sanakirjatyyppinen esitys suomen kielestä on 12 sanan lista, joka sisältyy saksalaisen maantieteilijän Sebastian Münsterin vuonna 1544 julkaisemaan Cosmographia-teokseen. Ensimmäiset suomea sisältäneet varsinaiset sanakirjat julkaistiin 1600-luvulla. Vanhin niistä on ruotsalaisen filologin Ericus Schroderuksen Lexicon Latino-Scondicum, joka ilmestyi vuonna 1637. Tuntemattoman tekijän Variarum rerum vocabula Latina, cum Svetica et Finnonica interpretatione ilmestyi vuonna 1644. Kolmannen sanakirjan, joka on nimeltään Nomenclatura Rerum brevissima, Latino-Sveco-Finnonica, julkaisi Paimion kirkkoherra Henricus Florinus vuonna 1678. Lisäksi tunnetaan saksalaisen historioitsijan Martin Fogelin painamaton sanakirjakäsikirjoitus Nomenclator Latino Finnicus vuodelta 1669. Kaikki neljä sanakirjaa ovat ns. tulkkisanakirjoja, joissa sanasto on jaettu aihepiireittäin eikä myöhemmin vakiintuneeseen tapaan aakkosjärjestykseen. Suomea sisältäviä sanakirjoja koskevassa kirjallisuudessa saattaa mainittujen lisäksi harvakseltaan törmätä kiinnostavaan nimeen: Lexicon pentaglotton in quo vocabulis latinis respondent graeca, suecica, germanica, fennica. Nimensä perusteella kyseessä on viisikielinen sanakirja, jonka hakukielenä on latina ja selityskielinä kreikka, ruotsi, saksa ja suomi. Sanakirjaa tai sen käsikirjoitusta ei kuitenkaan ole löytynyt eikä sen painamisesta ole mitään varmoja tietoja. Tutkimukseni ${ }^{1}$ tavoitteena on kartoittaa mahdollisimman tarkasti, millainen ja missä muodossa Lexicon pentaglotton aikanaan on ollut.

Luonteeltaan tutkimukseni on kirjahistoriallinen, mutta ei kuitenkaan tieteenalalle tavanomaisessa mielessä. Kirjahistoriallisessa tutkimuksessa lähestytään tutkimuskohdetta perinteisesti kahdesta eri näkökulmasta. Ensinnäkin on tärkeää tutkia kirjaa esineenä, esimerkiksi sen rakennetta ja painamisprosessia. Silloin saadaan usein viitteitä

1 Kiitän Kaisa Häkkistä ja Kirsi-Maria Nummilaa tutkimukseni kannalta oleellisista huomioista. 
esimerkiksi siitä, mitä kirjapainossa on tapahtunut ja keitä painotyöhön on osallistunut. Tällaista tutkimusta kutsutaan analyyttiseksi bibliografiaksi. (Laine 1996, 18.) Käsikirjoitusten osalta puhutaan myös kodikologiasta (ks. esim. Kallio 2012). Toiseksi on syytä perehtyä muuhun tutkittavan kirjan kannalta oleelliseen lähdemateriaaliin. Kirjahistorian tutkijan pitää siis turvautua historiantutkimuksen metodeihin, jotta tutkimuskohteen voi sijoittaa oikeanlaiseen yhteiskunnalliseen kontekstiin. (Laine 1996, 18-19.)

Tehtävä on tässä tapauksessa vaikea, koska varsinaiseen tutkimuskohteeseen ei voi suoraan päästä käsiksi. Bibliografinen tai kodikologinen analyysi ei siis tule kysymykseen. Näin ollen tutkimukseni nojaa yksinomaan sellaisiin havaintoihin, joita voi tehdä muualta kuin itse Lexicon pentaglottonia tarkastelemalla. Lisähaastetta tutkimukseen tuo se, että historialliset lähteet tarjoavat tietoa Lexicon pentaglottonista erittäin vähän, ja sekin tieto on hyvin epävarmaa. Tavoitteenani on kuitenkin arvioida näiden tietojen luotettavuutta ja paikkansapitävyyttä. Vähäisen lähdeaineiston takia tarkastelen aihetta myös 1600-luvun suomalaisen henkilöhistorian ja kirjojen julkaisuhistorian näkökulmista. Tällä tavalla muodostettu tutkimuskokonaisuus tarjoaa merkittävästi paremmat mahdollisuudet perehtyä Lexicon pentaglottoniin kuin vähäiset entuudestaan tunnetut historialliset maininnat. Tutkimukseni täydentää osaltaan 1600-luvulla tehtyjen suomea sisältävien sanakirjojen tutkimusta, jota aiemmin on harjoittanut erityisesti Kirsi-Maria Nummila (2010; 2012).

\section{Aiempi tutkimus vastaavista teoksista}

\subsection{0o-luvun suomea sisältävien sanakirjojen tutkimus}

Vanhoja sanakirjoja käsitellään enimmäkseen kirjahistoriallisissa yleisluontoisissa esityksissä (esim. Hakulinen 1967; Haugen 1984; Häkkinen 1994, 117-121; Lehtosalo-Kuutti 2013). Tieteellisiä tutkimuksia vanhoista sanakirjoista ja niiden sisällöistä on myös julkaistu. Birgitta Romppanen (2001) on väitöskirjassaan tutkinut suomea sisältävien sanakirjojen kehitystä. Nummila $(2010 ; 2012)$ puolestaan on tarkastellut 1600-luvun sanakirjojen suomalaissanaston alkuperää. Jari Ekberg (2009) on tutkinut pro gradu -tutkielmassaan Variarum rerum vocabulan tekijän nomininmuodostuskeinoja. Sanakirjoja on käytetty myös osana laajempaa tutkimusaineistoa esimerkiksi Nummilan (2006) tekemässä Henricus Florinuksen substantiivien muodostusta käsittelevässä tutkimuksessa. Mainitut tutkimukset poikkeavat kuitenkin omasta tutkimuksestani siinä suhteessa, että niissä tutkittava sanakirja on ollut tutkijan käsillä vähintäänkin kopioituna kappaleena. Sekä Romppanen (2001, 311-312) että Nummila (2010, 200) pitävät henkilöhistoriallista näkökulmaa antoisana, kun tutkitaan vanhoja sanakirjoja. Tässä mielessä tutkimukseni noudattaa siis aiemmin jo tutkimuskentällä tarpeelliseksi todettua lähestymistapaa. 


\subsection{Tuntemattomien teosten tutkimus}

Tutkimushistoria tuntee myös esimerkkejä tutkimuksesta, jossa pyritään selvittämään lisätietoa teoksesta, jota ei ole säilynyt yhtään kappaletta. Myös niissä henkilöhistoriallinen näkökulma on erittäin keskeinen. Vuodelta 1579 tunnetaan Antonio Possevino -nimisen kardinaalin maininta, jonka mukaan Olmützin jesuiittakollegiossa opiskellut suomalainen Olaus Sundergelteus olisi saanut tehtäväkseen kirjoittaa suomen kielen kieliopin (Mark 1949, 55). Julius Mark (mt., 58) arvelee, että kielioppi ei koskaan valmistunut. Lisäksi Olmützin jesuiittakollegiota käsittelevässä selostuksessa vuodelta 1583 mainitaan, että suomen kielioppia olisi ryhtynyt kirjoittamaan Johannes-niminen suomalaismies, jonka arvellaan olevan pappi Johannes Jussoila (Vihonen 1983, 122). Jussi Nuorteva $(1997,443)$ arvelee, että Jussoilan käsikirjoitus jäi painamatta ja on aikojen saatossa kadonnut.

Toinen esimerkki vastaavanlaisesta tutkimuksesta koskee myös kadonnutta suomen kielioppia. Naantalin kappalaisena vuosina 1634-1652 toiminut Henricus Crugerus laati kielioppikäsikirjoituksen, joka on sittemmin kadonnut. Crugeruksen kieliopin sisältöäkin tunnetaan jonkin verran, sillä tanskalaiset grammaatikot Erik Pontopiddan ja Peder Syv ovat hyödyntäneet sitä 1660- ja 1680-luvuilla omissa julkaisuissaan. (Mark 1949, 141-142; Vihonen 1983, 122.) Näin ollen Crugeruksen kielioppikirjan tutkimuksessa myös sen sisällön tutkiminen on mahdollista. Crugeruksen kieliopin sisältöä esittelevät Mark (1949), Sakari Vihonen (1978, 28-29) ja lyhyesti myös Pirkko Kuutti (2012, 18).

\section{Tutkimuskohde Lexicon pentaglotton ja sen huomioiminen tutkimuskirjallisuudessa}

Lexicon pentaglotton in quo vocabulis latinis respondent graeca, suecica, germanica, fennica mainitaan vuonna 1719 julkaistussa Aboa Literata -teoksessa². Aboa Literata on kirjallisuusluettelo, jossa on kirjattuna kaikki Turun akatemian piirissä julkaistu kirjallisuus. Sen kokosi nuori Anders Anton von Stiernman, josta myöhemmin tuli kansliakollegion sihteeri ja kanslianeuvos. Aboa Literataan kirjattujen tietojen perusteella Lexicon pentaglottonin on toimittanut ja julkaissut omalla kustannuksellaan Turun piispana ja Turun akatemian varakanslerina toiminut Johannes Gezelius vanhempi vuonna 1686.

Aboa Literataa myöhemmässä tutkimuskirjallisuudessa Lexicon pentaglottonista on muutama yksittäinen maininta. Nimen ovat tutkielmissaan maininneet esimerkiksi Louis Léouzon Le Duc (1845, CXXIV), Sven Gabriel Elmgren $(1861,96)$, M. Wasenius (1893, 401) ja Ernst Lagus (1890, liitesivu VII). Kirjan mainitsee myös yliopiston kirjastonhoitaja Fredrik Wilhelm Pipping, joka vuosina 1856-1857 kokosi suomenkielisten ja suomea

2 Aboa Literatasta on myöhemmin julkaistu näköispainos, jonka yhteydessä on Reijo Pitkärannan suomenkielinen käännös ja Matti Klingen jälkisanat. 
sisältävien teosten bibliografian ${ }^{3}$. Johannes Gezelius vanhemman henkilöhistoriikin vuonna 1825 julkaissut Johan Jakob Tengström ei mainitse Lexicon pentaglottonia. Hän on kuitenkin käyttänyt lähteenään Aboa Literataa (ks. esim. s. 241), joten sanakirjan poisjättäminen Gezeliuksen julkaisuista lienee ollut tietoinen valinta. Uudemmassa tutkimuskirjallisuudessa Lexicon pentaglotton mainitaan esimerkiksi Liisa Nuutisen toimittaman, vuonna 1997 julkaistun Christfried Gananderin käsikirjoituksesta toimitetun Nytt Finskt Lexicon -sanakirjan esipuheessa. Lisäksi Romppanen $(2001,121)$ on väitöskirjassaan pohtinut hyvin lyhyesti Lexicon pentaglottonin olemassaoloa ja arvelee, että se on saattanut olla vain jonkinlainen sanalista. Kirja on mainittu myös Suomen kansallisbibliografiassa, jonka tietoihin on lisätty oletus, että kirjanpainajana toimi Johan Winter Gezeliuksen itsensä perustamassa kirjapainossa.

Kaikki maininnat kirjasta pohjautuvat varmasti Aboa Literatan tietoihin joko suoraan tai välillisesti esim. Pippingin bibliografian kautta, sillä kukaan ei ole tutkimushistorian saatossa tarjonnut Lexicon pentaglottonista enempää tietoa kuin sen, mitä jo Aboa Literatasta löytyy. En ole löytänyt viitteitä siitä, että Lexicon pentaglottoniin liittyviä asioita olisi edes yritetty tutkia aiemmin.

\section{Tutkimuskysymykset Lexicon pentaglottonin tekijästä ja valmistumisesta}

\subsection{Lexicon pentaglottonin tekijä}

Epävarmojen historiallisten lähteiden täydentämiseksi on syytä tarkastella, miten Lexicon pentaglotton sopisi juuri Gezeliuksen ${ }^{4}$ tekemäksi. Sanakirja sisältää viittä kieltä: latinaa, kreikkaa, ruotsia, saksaa ja suomea. Näistä ruotsi on Gezeliuksen äidinkieli. Latinaa osasivat kaikki oppineet henkilöt, sillä se oli yliopistojen kieli. Ennen Turkuun muuttoaan Gezelius työskenteli Tarton yliopistossa kreikan ja itämaisten kielten professorina. Hän siis osasi myös kreikkaa. Saksan kielen taidosta todistaa Gezeliuksen julkaisema saksan kielioppi (ks. lisää Keinästö 2005). Gezeliuksen suomen kielen taidosta ei ole täyttä varmuutta. On esitetty arvioita, että hänen teoksiinsa sisältyvät suomenkieliset tekstit olisivat jonkun muun kääntämiä (esim. Laine 1997, 94-95). Gezelius julkaisi Yxi lasten paras tawara -aapiskatekismuksen vuonna 1666, mutta koska hän oli tullut Turkuun vasta pari vuotta aiemmin, ei hän todennäköisesti ole voinut kääntää tekstiä yksin. Aapiskatekismuksen suomi on kielellisesti moitteetonta. Tarvittaessa hän sai siis apua joltakulta suomea

3 Förteckning öfver i tryck utgifna skrifter på finska, äfvensom öfver några andra arbeten, innehållande någon uppsats på detta språk, eller annars ledande till dess kännedom - Luettelo suomeksi präntätyistä kirjoista, kuin myös muutamista muista teoksista, joissa löytyy joku kirjoitus suomen kielellä, tahi joku johdatus sitä tuntemaan. Teoksesta on myöhemmin toimittanut näköispainoksen Martti Rapola vuonna 1967.

4 Ilman erillisiä lähdeviitteitä Gezeliuksen henkilökohtaista elämää ja tuotantoa koskevat tiedot ovat peräisin Kansallisbiografiasta, jonka sisältö on saatavissa verkossa. Ks. Laasonen (1997). Vaihtoehtoisesti ks. Hyötyniemi (1947). 
paremmin taitaneelta kuten esimerkiksi Paimion kirkkoherralta Henricus Florinukselta, joka toimitti Gezeliuksen aloitteesta suomenkielisen, vuonna 1685 julkaistun Raamatun. Lisäksi merkittävä osa aapiskatekismuksen suomenkielisestä tekstistä on peräisin jo aiemmin suomeksi julkaistuista teoksista. (Häkkinen 2015, 13-15.) Varteenotettava ehdokas yhteistyölle on myös hyvästä kreikan kielen taidostaan tunnettu Turun akatemian itämaisten kielten professori Ericus Falander (ks. esim. Halén 1993, 142 ja Klinge 1987, 609). Günter Stipan (1990, 80) mukaan Paltamon kirkkoherralla Johan Cajanuksella olisi myös ollut samoihin aikoihin tekeillä suuri sanakirja, jota ei koskaan painettu ja jonka käsikirjoitustakaan ei tunneta. Vuonna 1667 Gezelius teki Paltamoon piispantarkastuksen, jota Cajanus isännöi (Virrankoski 1998).

Sanakirjojen tekijöillä ulkopuolisen avun käyttäminen on ollut tavanomainen käytäntö. Esimerkiksi Ericus Schroderus ilmoittaa itse Lexicon Latino-Scondicumin esipuheessa, että hän on saanut apua Marcus Björneburgikselta eli Marcus Sadelerukselta. Nummila $(2010,199)$ on todennut tutkimuksissaan, että Schroderuksen ilmoitus pitää paikkansa. Näin ollen ainakaan Lexicon pentaglottoniin sisältyviin kieliin ei liity mitään sellaista, mikä todistaisi Gezeliuksen osallisuutta vastaan.

Ruotsin vallan aikakaudella monilla suomeksi julkaistuilla ja suomea sisältävillä teoksilla oli jonkinlainen ulkomainen esikuva, jonka mallin mukaan teos tehtiin. Myös Gezelius on noudattanut tällaista menettelyä julkaisutoiminnassaan (Laasonen 1977, 370-382; Keinästö 2005, 266). Lexicon pentaglotton -nimellä on julkaistu 1600-luvulla toinenkin sanakirja. Wittenbergin yliopiston heprean kielen opettajan Valentin Schindlerin sanakirja Lexicon Pentaglotton: Hebraicum, Chaldaicum, Syriacum, Talmudico-Rabbinicum et Arabicum julkaistiin vuonna 1612. Siinä on edustettuna viisi Lähi-idän seemiläistä kielimuotoa ${ }^{5}$, joista tunnetuin Euroopassa on ollut sanakirjan hakukieli heprea. Sanat on aakkostettu heprean aakkosjärjestykseen. Gezeliuksen professorinvirkaan Tarton yliopistossa kuului Raamatun alkukielten opetus, joten hepreaakin hän osasi moitteetta. Lisäksi viranhoitoon kuului muitakin heprealle läheisiä seemiläisiä kieliä (Halén 1993, 133-135). Tiedossani ei ole yhtään säilynyttä Schindlerin sanakirjaa nyky-Suomessa, mutta ruotsalaisista kirjastoista löytyy useita kappaleita. Turun akatemian professorina vuosina 1654-1671 toimineen Petter Bergiuksen kotikirjastoon Schindlerin sanakirja on kuitenkin kuulunut (Halén 1993, 135-136). Se on siis ollut tuttu teos Pohjolassa ja saattoi hyvin kuulua myös Gezeliuksen henkilökohtaiseen kirjastoon. Hypoteesi esikuvateoksesta on toki hyvin epävarma, mutta kuitenkin hatarien faktojen valossa sinänsä mahdollinen.

Schindlerin sanakirjan kaltaiselle teokselle on ollut Suomessa varmasti kiinnostusta ja kysyntää, sillä samantyyppisiä teoksia on ollut esimerkiksi Turun akatemian kirjaston kokoelmissa. Turun akatemian kirjastonhoitaja Axel Kempen vuonna 1655 julkaisemasta bibliografiasta Bibliotheca Academiae Aboensis sive Elenchus käy ilmi, että Akatemian kirjaston kokoelmiin on kuulunut esimerkiksi Philipp Aquinasin Dictionarium Hebrao

5 Raamatullisen heprean ja arabian lisäksi siis kaldea ja syyria, jotka ovat aramean kielen muotoja. Talmudico-Rabbinicum viittaa ns. rabbiiniseen hepreaan. (Ks. esim. Harviainen 1993, 71.) 
Chaldaico-Talmudico-Rabbinicum ja Elias Hutterin Dictionarium Harmonicum Biblicum, Ebraeum, Graecum, Latinum, Germanicum. Lisäksi Valentin Schindlerin muutakin tuotantoa on ollut Suomessa, sillä akatemian kirjaston kokoelmiin on kuulunut myös mm. heprean kielioppi, jonka Schindler on toimittanut painoon Sebastian Münsterin aiemmin julkaiseman teoksen pohjalta. Nämä tiedot tukevat näkemystä, että myös Schindlerin Lexicon pentaglotton olisi ollut Turussa tarpeellinen teos.

Monikielisyys on ollut lähellä Gezeliuksen sydäntä, sillä hän julkaisi myös esimerkiksi kreikkalais-latinalaisen sanakirjan. Lisäksi hän julkaisi vuonna 1682 Orbis sensualium pictus -teoksen. Se on maailman olioita ja ilmiöitä kuvien avulla esittelevä teos, jossa kuvien yhteyteen saattoi lisätä selityksiä monilla eri kielillä. (Häkkinen 2015, 15.) Eri kielten vertailua harjoitti myös Gezeliuksen läheinen tuttava Georg Stiernhielm, joka ensimmäisten joukossa havaitsi unkarin ja suomen sukulaisuussuhteen (Korhonen 1986, 29). Hänen tutkimuksillaan on saattanut olla vaikutusta Gezeliuksen mielenkiinnon kohteisiin. Gezelius nimittäin arvosti Stiernhielmiä niin suuresti, että omisti hänelle julkaisemansa heprean kieliopin (Harviainen 1993, 86). Gezelius julkaisi vuonna 1688 tai 1689 oman bibliografiansa Index librorum \& tractatuum, mutta tässä julkaisussa ei mainita Lexicon pentaglottonia. Painoon se siis tuskin on päätynyt ainakaan vuoteen 1688 mennessä, johon asti kyseinen bibliografia yltää ajallisesti. Tengström $(1825,246)$ tosin huomauttaa Gezeliuksen bibliografiassa olevan virheitä ja puutteita.

\subsection{Lexicon pentaglottonin valmistuminen ja painaminen}

Kuten aiemmin kävi ilmi, tähän mennessä varhaisin tunnettu maininta Gezeliuksen Lexicon pentaglottonista on Aboa Literatasta vuodelta 1719. Sanakirjan arvellaan valmistuneen vuonna 1686, joten on syytä tarkistaa, olisiko Aboa Literataa vanhemmassa kirjallisuudessa mainintoja tai muita viitteitä siitä. Aboa Literatan tyylisiä bibliografioita on julkaistu muitakin. Vuonna 1680 julkaistiin postuumisti Johannes Schefferuksen kokoama bibliografia Svecia literata seu de scriptis \& scriptoribus gentis Sveciae. Teoksesta julkaistiin täydennetty laitos vuonna 1698. Bibliografia esittelee koko valtakunnassa julkaistuja teoksia, myös Suomessa painettuja siis. Sekä vuoden 1680 että vuoden 1698 Svecia literatassa mainitaan Johannes Gezelius vanhemman tiedoissa Lexicon pentaglotton. Tiedot kuitenkin poikkeavat tutkimukseni kannalta kiinnostavalla tavalla Aboa Literatan maininnasta. Svecia literatan koko tietue kuuluu Lexicon pentaglotton, in quo vocabulis latinis respondent graeca, suecica, germanica, fennica, quod hodie est sub manu. Svecia literatasta puuttuu siis tieto julkaisuvuodesta 1686, joka kuitenkin löytyy Aboa Literatasta. Sen sijaan Aboa Literatasta taas puuttuu Svecia literataan sisältyvä maininta, joka edellä on korostettu lihavoidulla fontilla. Tämä maininta tarjoaa ensimmäisen kerran Lexicon pentaglottonin tutkimushistoriassa mahdollisuuden tehdä sellaisia päätelmiä, joita aiemmin pelkästään Aboa Literatan tietoihin perustavissa esityksissä ei ole voitu tehdä. 
Latinankielisen lauseen voisi asiayhteydestä riippuen kääntää usealla eri tavalla ${ }^{6}$, mutta tässä tapauksessa konteksti rajaa mahdolliset merkitykset siten, että sanakirja on sekä vuonna 1680 että vuonna 1698 todennäköisesti ollut joko 'käsillä' tai 'työn alla'. Ensimmäinen tulkinta viittaisi kenties siihen, että käsikirjoitus on valmistunut. Toinen luonnollisesti taas siihen, että käsikirjoitus on ollut molempina Svecia literatan julkaisuvuosina yhä keskeneräinen. Keskeneräisyyden puolesta puhuu se, että sekä Svecia literatan että Aboa Literatan tiedoissa muiden Gezeliuksen julkaisujen kohdalla mainitaan kirjan koko, mutta Lexicon pentaglottonin kohdalla tämä tieto puuttuu. Johannes Gezelius vanhempi on kuollut vuonna 1690. Jos käsikirjoitus on vielä siinä vaiheessa ollut keskeneräinen tai jostain muusta syystä painamaton, on ymmärrettävää, että painettua kirjaa ei koskaan tehtykään. Svecia literatan eri painosten tiedoissa on huomioitava se, että myöhemmän painoksen toimittaja ei välttämättä ole päivittänyt tietojaan niiden teosten osalta, jotka ensimmäisessä painoksessa on kirjattu keskeneräisiksi. Esimerkiksi vuoden 1698 painoksessa mainitaan Gezeliuksen tiedoissa, että Didactica sacra -teos on niin ikään sub manu, siis oletettavasti keskeneräinen. Kuitenkin Aboa Literatassa tiedetään kertoa, että kyseinen käsikirjoitus tuhoutui Turun palossa jo vuonna 1681.

Muutamia vuosia ennen Lexicon pentaglottonin oletettua ilmestymisajankohtaa julkaistiin Henricus Florinuksen latinalais-ruotsalais-suomalainen Nomenclatura-sanakirja. Gezeliuksen kuoleman jälkeen julkaistuun Nomenclaturan painokseen (1695) lisättiin myös saksan kieli. Saksankielistä täydennystä Florinus ei tosin itse työstänyt, ja oikea kääntäjä on jäänyt tuntemattomaksi (Häkkinen-Keinästö 2009, 6). Nomenclatura on tutkimustyöni kannalta kiinnostava teos, joka on voinut vaikuttaa siihen, että Lexicon pentaglottonia ei koskaan julkaistu. Palaan tähän näkökulmaan hieman edempänä.

\section{Pohdintaa}

Edellä esiteltyjen tietojen perusteella Lexicon pentaglottonin taustaa ja kohtaloa voidaan siis pohtia muutamalta eri kannalta. Ensinnäkään ei ole syytä epäillä Gezeliuksen osallisuutta. Svecia literatasta löytyvää aikalaismainintaa voinee pitää luotettavana lähteenä. Lisäksi Gezeliuksen kielitaito ja muut julkaisut tukevat näkemystä, että juuri hän olisi ryhtynyt kokoamaan sanakirjaa, joka sisältää latinaa, kreikkaa, ruotsia, saksaa ja suomea. Koska tieto sanakirjan tekemisestä on kiirinyt Ruotsiin Svecia literatan kokoajalle, voi nähdäkseni olettaa, että Lexicon pentaglotton on ollut merkittävämpi hanke kuin pelkkä vaatimaton sanalista. Svecia literatan koonnut Johannes Schefferus kuoli vuonna 1679. Gezeliuksen on siis pitänyt aloittaa sanakirjaprojektinsa jo tätä ennen, jotta Schefferus on voinut saada tiedon asiasta. Todennäköisesti Gezelius on työstänyt sanakirjaa yhdessä jonkun muun, esimerkiksi Henricus Florinuksen, Ericus Falanderin tai jopa Johan

6 Kiitän Veli-Matti Rissasta avusta latinan kielen tulkitsemisessa. 
Cajanuksen kanssa. Mahdollisesti vastuu toimitustyöstä on kuulunut kokonaisuudessaan jollekulle muulle kuin Gezeliukselle itselleen.

Toiseksi voi pohtia, olisiko Gezeliuksen sanakirjan esikuvateoksena toiminut juuri Schindlerin julkaisema seemiläiskielten Lexicon pentaglotton. Tätä yhteyttä ei tietenkään voi osoittaa todeksi, ellei Gezeliuksen sanakirja joskus ilmaannu tutkittavaksi, mutta asiaa ei nytkään pidä täysin sivuuttaa. Ainoa selkeä yhteys vähäisillä tiedoillamme teosten välillä on nimi, mutta Lexicon pentaglotton ei ole ollut mikään yleispätevä tapa nimittää viisikielisiä sanakirjoja Euroopassa. Koska seemiläiskielten sanakirja on ollut Pohjolassa tunnettu ja Gezeliuksella tiedetään olleen perehtyneisyyttä juuri seemiläisiin kieliin, on perusteltua olettaa, että hänen asemassaan oleva henkilö on voinut hyvin hankkia kirjan kokoelmaansa tai on ainakin tutustunut siihen jossain muualla kuin Turussa. Suomea sisältävät 1600-luvun sanakirjat ovat tulkkisanakirjoja, mutta Schindlerin sanakirja on massiivinen aakkostettu teos. Mahdollisesti Gezeliusta on miellyttänyt vain sanakirjan nimi. Mikäli Gezelius on todella yrittänyt jäljitellä Schindlerin sanakirjaa myös rakenteellisesti ja sisällöllisesti, on hanke saattanut kaatua omaan mahdottomuuteensa jo pelkästään työmäärän takia.

Lisäksi oleellinen pohdittava seikka on, onko Lexicon pentaglotton valmistunut ja painettu. Svecia literatasta löytyneen lisätiedon valossa voi olettaa, että sanakirja on varmasti ollut tekeillä. Tähän ei vaikuta se, kumman edellä mainituista latinan kielen tulkinnoista valitsemme näkökannaksemme. Ne vähäiset tiedonmuruset, joita Lexicon pentaglottonista on saatavilla, eivät kuitenkaan riitä varmistamaan sitä, että käsikirjoitus olisi tullut koskaan valmiiksi. Todennäköisesti ei ole, sillä Gezelius ei ole maininnut sanakirjaa bibliografiassaan. Von Stiernman on mahdollisesti kirjoittanut Aboa Literataan tiedon sanakirjasta siksi, että se mainitaan Svecia literatassa. Koska aikaa oli kulunut 1700-luvun alkupuolelle saakka, lienee von Stiernman olettanut sanakirjan valmistuneen ja on siksi poistanut Svecia literatassa olleen latinankielisen lisätiedon. Koska kuitenkin poikkeuksellisesti juuri Lexicon pentaglottonin kohdalla puuttuu kirjan kokomerkintä myös Aboa Literatasta, voi olettaa, että von Stiernmanilla ei ole ollut todellista tietoa kirjan valmistumisesta.

Kukaties Gezeliuksen kuolema vuonna 1690 on keskeyttänyt käsikirjoituksen laatimisen, eikä hänen poikansa ja seuraajansa Johannes Gezelius nuorempi ole kyennyt sitä syystä tai toisesta jatkamaan. Missään tapauksessa Gezelius nuorempi ei ollut likimainkaan yhtä tuottoisa kirjojen julkaisija kuin isänsä. Myös Henricus Florinus on saattanut vaikuttaa siihen, että Lexicon pentaglotton ei koskaan päätynyt painoon asti. Koska hänen Nomenclatura-sanakirjansa oli julkaistu muutamia vuosia aiemmin, ei Lexicon pentaglottonia katsottu välttämättömäksi painaa etenkin jos saksaa sisältävä Nomenclaturan uusintapainos oli jo suunnitteilla. Tarvetta toki olisi ollut erityisesti sellaiselle sanakirjalle, jossa sekä suomi että kreikka olisivat ensimmäistä kertaa yksissä kansissa, mutta aiemmin julkaistu kreikkalais-latinalainen sanakirja kenties täydensi tätä puutosta.

Tiivistetysti ilmaistuna pidän erittäin todennäköisenä sitä, että Lexicon pentaglotton todella oli Johannes Gezelius vanhemman käynnistämä sanakirjahanke, joka oli mitä luultavimmin ainakin osittain jonkun toisen henkilön toimitettavaksi annettu ja joka 
valitettavasti kariutui ennen valmistumistaan. Tarkempaa tietoa asiasta on jokseenkin mahdotonta saada, ellei sanakirjan käsikirjoitusta tai sen osaa joskus ilmaannu arkistojen kätköistä. Eräs todennäköinen vaihtoehto on, että mikäli Gezeliuksen käsikirjoitus on aikanaan katsottu aiheelliseksi säästää, on se lopulta tuhoutunut Turun akatemian kirjaston tulipalossa vuonna 1827. Myös tuhoutuminen vuoden 1681 tulipalossa on periaatteessa mahdollista, kuten kävi Didactica sacra -teoksen käsikirjoitukselle. Se on kuitenkin epätodennäköistä. Uskon, että von Stiernmanilla on ollut tiedossaan jonkinlainen aikalaishavainto tai kirjallinen maininta, joka on todistanut, että käsikirjoitus on ollut olemassa vielä vuonna 1686. En kuitenkaan tutkimuksessani kyennyt varmistamaan kyseiselle vuosiluvulle mitään selkeää syytä.

Tutkimukseni tukee aiemmin esitettyjä näkemyksiä, että kirjahistoriallisessa tutkimuksessa oleellista on myös historiantutkimuksen keinoin tutkia varsinaista tutkimuskohdetta ympäröivää maailmaa. Vaikka tutkittavasta kirjasta tai käsikirjoituksesta itsestään olisi niukasti tietoa saatavilla, erityisesti henkilöhistoriallinen tutkimus saattaa tarjota lisävalaistusta moneen kysymykseen. Henkilöhistoriallisen tutkimuksen tulokset puolestaan johdattelevat tutkijan tutkimuksen kannalta oleellisten tapahtumien ja ajanjaksojen äärelle, minkä ansiosta tutkimuksesta muodostuu monipuolinen kokonaisuus.

\section{Lähteet}

Aquinas, Philipp 1529: Dictionarium Hebrao Chaldaico-Talmudico-Rabbinicum. Paris.

Ekberg, Jari 2009: Nomininmuodostuskeinot tulkkisanakirjassa Variarum Rerum Vocabula. Pro gradu -tutkielma. Turun yliopisto, Turku.

Elmgren, Sven Gabriel 1861: Öfversigt af Finlands Litteratur ifrån år 1542 till 177o. J. C. Frenckell \& Son, Helsingfors.

Florinus, Henricus 1678: Nomenclatura Rerum brevissima, Latino-Sveco-Finnonica. Näköispainos. Suomalaisen Kirjallisuuden Seura, Helsinki 1976.

Fogel, Martin 1669: Nomenclator Latino Finnicus. Käsikirjoitus.

Ganander, Christrried 1997: Nytt Finskt Lexicon. Toim. Lissa NuUtinen. Suomalaisen Kirjallisuuden Seura, Helsinki.

GeZelius, JohanNes 1688 tai 1689: Index librorum \& tractatuum \& $c$. \& c. (cura [et] sumptibus J. G. d. ep. Ab.) Variis locis \& temporibus, maximam partem recentioribus annis, in usum ecclesiae \& scholarum in magno ducatu Finlandiae, editorum. Aboae.

Hakulinen, Lauri 1967: Suomen sanakirjoista. Lauri Hakulinen, Osmo Ikola ja Paavo Ravila (toim.): Kirjoituksia suomen kielestä, 83-107. Suomalaisen Kirjallisuuden Seura, Helsinki.

HALÉN, HARRY 1993: Luettelo itämaisten kielten opettajista ja opetuksesta Turun akatemiassa 1640-1828. Ilkka Antola ja Harry Halén (toim.): Suomalaisen eksegetiikan ja orientalistiikan juuria, 133-160. Suomen Kirkkohistoriallinen Seura, Helsinki.

Harviainen, TAPANi 1993: Simon Paulinus - 300 vuotta ensimmäisen heprean kieliopin ilmestymisestä Suomessa. Ilkka Antola ja Harry HaléN (toim.): Suomalaisen eksegetiikan ja orientalistiikan juuria, 71-103. Suomen Kirkkohistoriallinen Seura, Helsinki.

Haugen, Eva L. 1984: A Bibliography of Scandinavian Dictionaries. Kraus International Publications, White Plains.

Hutter, Elias 1598: Dictionarium Harmonicum Biblicum, Ebraeum, Graecum, Latinum, Germanicum. Noriberg. 
Hyötyniemi, J. E. 1947: Juhana Gezelius vanhempi 1615-1690. Jaакко HaAvio (toim.): Mikael Agricolasta E. W. Pakkalaan. Suomen kirkon paimenien elämäkerrasto, 67-81. WSOY, Porvoo - Helsinki.

HäKkInen, KAISA 1994: Agricolasta nykykieleen. Suomen kirjakielen historia. WSOY, Porvoo - Helsinki - Juva.

HäKKInen, KaISA 2015: Johannes Gezelius vanhempi, Suomen kansan opettaja. Bibliophilos 4/2015, 11-16. Bibliofilien Seura ry, Helsinki.

HÄKKINEN, KAISA - KeINÄSTÖ, KARI 2009: Zu Geschichte und Wandel der Wörterbücher des Sprachenpaares Deutsch-Finnisch mit einem Überblick über die historische Stellung des Deutschen in Finnland. Ural-Altaische Jahrbücher. Neue Folge. Band 23, 1-19. Societas Uralo-Altaica, Göttingen.

Kallio, Maria 2012: Westhin koodeksin kodikologiaa. KaISA HäKkinen (toim.): Tutkimuksia Westhin koodeksista, 10-28. Turun yliopiston suomen kielen ja suomalais-ugrilaisen kielentutkimuksen oppiaineen julkaisuja 2. Turun yliopisto, Turku.

KeINÄstö, KARI 2005: Johannes Gezelius vanhempi ja Grammaticae Germanicae synopsis. JoHn SMEDS, Katri Sarmavuori, Eero laakkonen ja Rudolf de Cillia (toim.): Multicultural Communities, Multilingual Practice. Monikulttuuriset yhteisöt, monikielinen käytäntö. Festschrift für Annikki Koskensalo zum 6o. Geburtstag, 263-271. Turun yliopisto, Turku.

Kempe, Axel 1655: Bibliotheca Academiae Aboensis sive Elenchus. Aboae.

Klinge, Matti 1987: Teologia ja pyhät kielet. Helsingin yliopisto 1640-199o. Ensimmäinen osa. Kuninkaallinen Turun akatemia 1640-1808, 600-615. Kirjoittaneet Matti Klinge, Rainer Knapas, Anto Leikola ja John Strömberg. Otava, Helsinki.

Korhonen, Mikкo 1986: Finno-Ugrian Language Studies in Finland 1828-1918. Societas Scientiarum Fennica, Helsinki.

Kuntti, Pirkкo 2012: Varhaisimmat suomen kieliopit, Rudimenta ja Stahlin viron kielioppi. Petri Lauerma (toim.): Rudimenta linguae Finnicae breviter delineata. Suomen kielen varhaiskielioppi ja sen tausta, 17-23. Suomalaisen Kirjallisuuden Seura, Helsinki.

LaAsonen, Pentti 1977: Johannes Gezelius vanhempi ja suomalainen täysortodoksia. Suomen Kirkkohistoriallinen Seura, Helsinki.

1997: Gezelius, Johannes vanhempi (1615-1690). Kansallisbiografia-verkkojulkaisu. Suomalaisen Kirjallisuuden Seura, Helsinki. Verkko-osoite http://www.kansallisbiografia.fi/kb/artikkeli/2252/. Viitattu 2.2.2017.

LAGUS, ERNST 1890: Studier i den klassiska språkundervisningens historie i Finland med afseende fäst vid förhållandena i Sverige och andra länder. Väitöskirja. Helsingfors.

LAINE, TuIjA 1996: Kirjahistorian tutkimustraditiot ja nykytila. TuIjA LaIne (toim.): Kirjahistoria. Johdatus vanhan kirjan tutkimukseen, 11-34. Suomalaisen Kirjallisuuden Seura, Helsinki.

1997: Johannes Gezelius vanh.: Yxi paras lasten tawara, 1666; Ett rätt barna-klenodium, 1666. Tuija Laine (toim.): Vanhimman suomalaisen kirjallisuuden käsikirja, 93-96. Suomalaisen Kirjallisuuden Seura, Helsinki.

Lehtosalo, Kaisa - KuUtti, Pirkko 2013: Sanakirja historiassa, historia sanakirjassa. Laura TyysteRI ja KaIsA Lehtosalo (toim.): Hyvä sanakirja. Tieteellisiä, käytännöllisiä ja eettisiä näkökulmia leksikografiaan, 53-76. Turun yliopisto, Turku.

LÉouzon Le DuC, Louis 1845: La Finlande: son histoire primitive, sa mythologie, sa poésie épique; avec la traduction complète de sa grande epopée : Le Kalewala : son génie national, sa condition politique et sociale depuis la conquète russe. Jules Labitte, Paris.

Mark, Julius 1949: Die finnische Grammatik von Henricus Crugerus. Finnisch-Ugrische Forschungen XXX, 55-146. Suomalais-Ugrilainen Seura, Helsinki.

Münster, Sebastian 1544: Cosmographia. Basel.

Münster, Sebastian - Schindler, VAlentin 1612: Grammatica Hebraica. Basel \& Vitteberga.

Nummila, Kirsi-Maria 2006: Havaintoja substantiivien muodostuksesta Henrik Florinuksen sanaston ensiesiintymissä 1678-1693. Sananjalka 48, 7-28. Suomen Kielen Seura, Turku.

2010: 1600-luvun sanakirjojemme suomalaissanasto ja sen alkuperä. SIRKKa SAARINEN, KirsTi 
Sirtonen ja Tanja Vaittinen (toim.): Sanoista kirjakieliin. Juhlakirja Kaisa Häkkiselle 17. marraskuuta 2010, 189-202. Suomalais-Ugrilainen Seura, Helsinki.

Nummila, Kirsi-Maria 2012: Martin Fogelin sanakirjakäsikirjoitus Nomenclator Latino Finnicus 1669. Sananjalka 54, 163-169. Suomen Kielen Seura, Turku.

NuORTEVA, JUSSI 1997: Suomalaisten ulkomainen opinkäynti ennen Turun akatemian perustamista 1640. Suomen historiallinen seura, Helsinki.

Pipping, Fredrik Wilhelm 1856-1857: Förteckning öfver i tryck utgifna skrifter på finska, äfvensom öfver några andra arbeten, innehållande någon uppsats på detta språk, eller annars ledande till dess kännedom. Luettelo suomeksi präntätyistä kirjoista, kuin myös muutamista muista teoksista, joissa löytyy joku kirjoitus suomen kielellä, tahi joku johdatus sitä tuntemaan. Näköispainos 1967. Finska litteratur-sällskapet, Helsingfors.

Romppanen, Birgitta 2001: Från målspråk till källspråk. Utvecklingen av den finsk-svenska och den enspråkiga finska ordboken. Väitöskirja. Vaasan yliopisto, Vaasa.

SCHEFferus, Johannes 1680: Joannis Schefferi Argentoratensis Svecia literata seu de scriptis et scriptoribus gentis Sveciae. Opus postumum. Henrici Keyser, Holmiae.

SChefferus, Johannes - Mollerus, Johannes 1698: Svecia literata seu de scriptis \& scriptoribus gentis Sveciae: Opus postumum. Holmiae initio anno 1680, excusum, nunc autem denuo emendatius editum. Hamburgi.

Schindler, Valentin 1612: Lexicon Pentaglotton: Hebraicum, Chaldaicum, Syriacum, Talmudico-Rabbinicum et Arabicum. Hanoviae.

Schroderus, Ericus 1637: Lexicon latino-scondicum. Näköispainos. Toimittanut Bengt Hesselman. Almqvist \& Wiksell, Uppsala 1937.

STIPA, GÜNTER 1990: Finnisch-ugrische Sprachforschung. Von der Renaissance bis zum Neupositivismus. Suomalais-Ugrilainen Seura, Helsinki.

Suomen kansallisbibliografia. Sähköisessä muodossa osoitteessa https://www.kansalliskirjasto.fi/fi/ node/161. Viitattu 2.2.2017.

Tengström, Johan Jаков 1825: Biskopen i Åbo stift Johan Gezelii den äldres minne. Hjelt, Åbo.

Variarum rerum vocabula Latina, cum Svetica et Finnonica interpretatione. Holmiae 1644.

VihONen, SAKari 1978: Suomen kielen oppikirja 160o-luvulla. Kieliopillinen ajattelu 160o-luvun suomen kielen oppikirjoissa. Väitöskirja. Jyväskylän yliopisto, Jyväskylä.

1983: Suomen kielen kuvaus 160o-luvun kieliopeissa. Pentti Laasonen, Simo Heininen, Seppo J. Salminen ja Jussi Nuorteva (toim.): Collegium scientiae. Suomen oppihistorian kehityslinjoja keskiajalta Turun akatemian alkuaikoihin, 121-155. Suomen Kirkkohistoriallinen Seura, Helsinki.

Virrankoski, Pentti 1998: Cajanus, Johan (1626-1703). Kansallisbiografia-verkkojulkaisu. Suomalaisen Kirjallisuuden Seura, Helsinki. Verkko-osoite http://www.kansallisbiografia.fi/kb/artikkeli/2302/. Viitattu 12.2.2017.

von Stiernman, Anders Anton 1719: Aboa Literata. Turun akatemian kirjallisuus. Suomentanut Reijo Pitkäranta, jälkisanat Matti Klinge. Suomalaisen Kirjallisuuden Seura, Helsinki 1990.

WASENIUs, M. 1893: Liste des manuels français, d'allemand et d'anglais publiés par des auteurs finlandais ou parus en Finlande 1600-1892. Mémoires de la Société néo-philologique a Helsingfors I, 393-409. Société néo-philologique a Helsingfors, Helsingfors. 


\section{HaRri UUSITAlo: Lexicon pentaglotton - A Pentalingual Dictionary with Finnish}

The first dictionaries which included Finnish were published in the $17^{\text {th }}$ century. They were Lexicon Latino-Scondicum, Variarum rerum vocabula and Nomenclatura Rerum brevissima. Moreover, there is one unpublished manuscript known called Nomenclator Latino Finnicus. A fifth title also seems to appear in historical sources every so often: Lexicon pentaglotton in quo vocabulis latinis respondent graeca, suecica, germanica, fennica, supposedly printed or finished in 1686 . Prior to this study, the earliest known mention of Lexicon pentaglotton can be found in the book Aboa Literata which was published 1719. This study shows that Lexicon pentaglotton had been mentioned prior to that point.

The aim of this study is to find out whether the historical information about Lexicon pentaglotton is reliable and correct. Since the book itself no longer exists and the historical information is very uncertain, the viewpoints of $17^{\text {th }}$ century personal history and historical bibliography must be applied to this study. By combining historical information, some assumptions and conclusions related to Lexicon pentaglotton can be made.

My research shows that the preconception of Johannes Gezelius the Elder being the author of Lexicon pentaglotton may be considered to be reliable. However, one must take into consideration that he may have gotten assistance from someone else. Gezelius possibly used another book, which was also entitled Lexicon pentaglotton, as an exemplar to this dictionary. This book was published in 1612 and it includes five Semitic languages. It is likely that Gezelius's Lexicon pentaglotton was never published. Moreover, the manuscript was probably unfinished.

Harri Uusitalo

harri.uusitalo@utu.fi

Suomen kieli ja suomalais-ugrilainen kielentutkimus

20014 Turun yliopisto 